(c) American Dairy Science Association, 2006.

\title{
Technical Note: Improved Method for Rapid DNA Extraction of Mastitis Pathogens Directly from Milk
}

\author{
P. Cremonesi, ${ }^{\star 1}$ B. Castiglioni,† G. Malferrari,‡ I. Biunno,§ C. Vimercati,\# \\ P. Moroni,\# S. Morandi, $\|$ and M. Luzzana* \\ *Department of Biomedical Sciences and Technologies, University of Milan, Segrate, Milan, Italy \\ †Institute of Agricultural Biology and Biotechnology-Italian National Research Council, Milan, Italy \\ $\ddagger$ Center for Bio-Molecular Interdisciplinary Studies and Industrial Applications (CISI), University of Milan, \\ Segrate, Milan, Italy \\ §Institute of Biomedical Technologies-Italian National Research Council, Segrate, Milan, Italy \\ \#Department of Animal Pathology, Hygiene and Veterinary Public Health University of Milan, Italy \\ |IInstitute of Sciences of Food Production-Italian National Research Council, Milan, Italy
}

\begin{abstract}
Efficient control against bovine mastitis requires sensitive, rapid, and specific tests to detect and identify the main bacteria that cause heavy losses to the dairy industry. Molecular detection of pathogenic microorganisms is based on DNA amplification of the target pathogen. Therefore, efficient extraction of DNA from pathogenic bacteria is a major step. In this study, we aimed to develop a specific, sensitive, and rapid method to extract DNA directly from the main gram-positive bacteria known to cause bovine mastitis (Staphylococcus aureus, Streptococcus agalactiae, Streptococcus dysgalactiae, and Streptococcus uberis) found in milk samples. The DNA extraction method is based on the lysing and nuclease-inactivating properties of the chaotropic agent, guanidinium thiocyanate, together with the nucleic acid-binding properties of the silica particles. An efficient protocol consisting of 6 basic steps ( 3 of which were done twice) was developed and applied directly to milk samples. Absence of PCR inhibitors and DNA quality were evaluated by PCR amplification of the species-specific DNA sequences of the target bacteria. The level of sensitivity achieved in our experiments is applicable to milk sample analysis without sample enrichment.
\end{abstract}

Key words: milk, DNA extraction, Staphylococcus aureus, streptococci

\section{INTRODUCTION}

Mastitis (inflammation of the mammary gland) is a multifactorial disease and one of the most difficult pathologies to control. It can result from trauma or injury to the udder, chemical irritation, or from infec-

Received February 24, 2005.

Accepted August 29, 2005.

${ }^{1}$ Corresponding author: paola.cremonesi@unimi.it tion caused by different bacterial species. Mastitis is the single most costly disease of dairy cattle resulting in the reduction of milk yield and quality. The estimated annual losses due to mastitis are about $\$ 184$ per cow. These costs include reduced production, discarded milk, drug therapy, veterinarian costs, premature culling, and increased labor (National Mastitis Council, 1998).

Microorganisms that cause mastitis are generally classified as either contagious or environmental based upon their primary reservoir and mode of transmission. Staphylococcus aureus and Streptococcus agalactiae are contagious pathogens and are commonly transmitted among cows by contact with infected milk. These pathogens are of particular importance because they cause mainly subclinical forms of IMI that are often difficult to detect by the herdsman. Primary environmental pathogens include 2 types of bacteria: coliform species (e.g., Escherichia coli, Klebsiella) and species of streptococci other than Strep. agalactiae. These bacteria arise from the environment in which the cow lives, entering into the udder between milkings, when teats are exposed to mud, manure, and dirty bedding materials.

Current identification methods are based on microbiological culture of milk and biochemical tests on the isolated bacteria, according to the National Mastitis Council guidelines (1998). At present, species identification by standard methods is labor intensive and takes at least 2 to $3 \mathrm{~d}$ to yield a positive result.

Due to limitations of culture methods, approaches using PCR have been developed to identify mastitis pathogens. Development of PCR-based methods provides a promising option for the rapid identification of bacteria. Species-specific DNA sequences such as the highly conserved rRNA genes or the 16S-23S rRNA intergenic spacer of the ribosomal RNA operon can be used for the identification of bacterial species in hours, rather than days. Moreover, the sensitivity of PCRbased assays tends to be superior to bacterial cultures (Forsman et al., 1997; Phuektes et al., 2003) allowing 
Table 1. Genomic DNA extraction protocol

\begin{tabular}{ll}
\hline Step & Procedure \\
\hline 1 & $\begin{array}{l}\text { Dilute } 500 \mu \mathrm{L} \text { of milk sample with } 500 \mu \mathrm{L} \text { of sterilized saline solution }(\mathrm{NaCl} 0.9 \%) \text { and } \\
\text { centrifuge for } 15 \mathrm{~min} \text { at } 600 \times g \text { at } 4^{\circ} \mathrm{C} \text {; discard the supernatant. Repeat the step once. }\end{array}$ \\
& $\begin{array}{l}\text { Add } 300 \mu \mathrm{L} \text { of lysis buffer }{ }^{1} \text { and } 200 \mu \mathrm{L} \text { of binding solution }{ }^{2} \text { to the pellet resuspended in } 50 \\
\mu \mathrm{L} \text { of saline solution. Mix and incubate for } 5 \mathrm{~min} \text { at room temperature. Centrifuge for } 30 \mathrm{~s} \text { at }\end{array}$ \\
& $\begin{array}{l}450 \times g \text { and discard the supernatant. } \\
\text { Add } 200 \mu \mathrm{L} \text { of lysis buffer }{ }^{1} \text { and mix well. Centrifuge for } 30 \mathrm{~s} \text { at } 450 \times g \text { and discard the }\end{array}$ \\
& $\begin{array}{l}\text { supernatant. Repeat this step once. } \\
\text { Add } 200 \mu \mathrm{L} \text { of washing solution }{ }^{3} \text { and mix well. Centrifuge for } 30 \mathrm{~s} \text { at } 450 \times g \text { and discard the }\end{array}$ \\
& $\begin{array}{l}\text { supernatant. Repeat this step once. } \\
\text { Add } 200 \mu \mathrm{L} \text { of absolute ethanol solution and mix well. Centrifuge for } 30 \mathrm{~s} \text { at } 450 \times g \text { and }\end{array}$ \\
& $\begin{array}{l}\text { discard the supernatant. Vacuum-dry the pellet in an Eppendorf heat block for } 10 \text { min. } \\
\text { Add } 100 \mu \mathrm{L} \text { of elution buffer, }{ }^{4} \text { resuspend the pellet, and incubate for } 15 \text { min at } 65^{\circ} \mathrm{C} .\end{array}$ \\
& $\begin{array}{l}\text { Centrifuge for } 5 \text { min at } 450 \times g \text { and transfer the supernatant in a clean tube. To increase } \\
\text { the DNA yield, a second elution step (with } 5 \text { min heating) may be performed. }\end{array}$ \\
\hline
\end{tabular}

\footnotetext{
${ }^{1}$ Lysis buffer: $3 M$ guanidine thiocyanate, $20 \mathrm{~m} M$ EDTA, $10 \mathrm{~m} M$ Tris-HCl (pH 6.8), $40 \mathrm{mg} / \mathrm{mL}$ Triton X$100,10 \mathrm{mg} / \mathrm{mL}$ DL-dithiothreitol.

${ }^{2}$ Binding solution: $40 \mathrm{mg} / \mathrm{mL}$ silica (Sigma Aldrich, Milan, Italy) suspended in lysis buffer.

${ }^{3}$ Washing solution: 25\% absolute ethanol, 25\% isopropanol, $100 \mathrm{~m} M \mathrm{NaCl}, 10 \mathrm{~m} M$ Tris-HCl, $\mathrm{pH} 8$.

${ }^{4}$ Elution buffer: $10 \mathrm{~m} M$ Tris-HCl, $\mathrm{pH}$ 8.0, $1 \mathrm{~m} M$ EDTA.
}

the detection of small numbers of microorganisms. These factors can be extremely important when rapid and accurate identification of pathogenic bacteria is required.

Different PCR-based methods have been developed for specific and sensitive detection of mastitis pathogens in milk (Forsman et al., 1997; Phuektes et al., 2001; Riffon et al., 2001; Meiri-Bendek et al., 2002; Phuektes et al., 2003; Cremonesi et al., 2005). Direct isolation of high-quality DNA from the target bacteria found in milk, however, is often problematic and may require overnight selective-enrichment procedures (Phuektes et al., 2001; Meiri-Bendek et al., 2002; Ramesh et al., 2002). First, these difficulties are due to small concentrations of the pathogenic DNA present in a typical sample. Second, various factors affect DNA recovery, including the degree of cellular lysis, binding of DNA to particulate material, and degradation or shearing of DNA. Furthermore, in the case of grampositive bacteria such as Staph. aureus and streptococci, an optimal sample processing method should efficiently lyse resistant bacterial cell walls without damaging target DNA. In addition, many current methods typically require multiple steps or specialized equipment, rendering them impractical for use with large sample numbers (Boom et al., 1990). Finally, direct detection of pathogenic bacteria in food samples (Ramesh et al., 2002) is hampered by the presence of PCR-inhibitory substances frequently associated with the food matrix itself (Rossen et al., 1992). Particularly in milk, components such as $\mathrm{Ca}^{2+}$, proteinase, fats, and milk proteins may block DNA and shield it from access by polymerase (Wilson, 1997). Consequently, the development of a sample preparation strategy that can effec- tively sequester high-quality DNA of the pathogenic bacteria from food samples before PCR amplification is needed.

In this paper, we describe a method for rapid DNA extraction directly from bovine and caprine raw milk to obtain material for PCR detection of gram-positive bacteria such as Staph. aureus, Strep. agalactiae, Strep. uberis, and Strep. dysgalactiae. This method is based on the ability of silica resin to bind DNA in the presence of high concentrations of guanidine thiocyanate as described previously (Malferrari et al., 2002), which guarantees excellent disruption of bacterial cells.

\section{MATERIALS AND METHODS}

\section{DNA Extraction}

Our DNA extraction procedure is described in Table 1. For preliminary experiments, sterile saline solution and sterile bovine milk were inoculated with $<10$ to $10^{7} \mathrm{cfu} / \mathrm{mL}$ of the Staph. aureus ATCC 23235 reference strain and Strep. agalactiae, Strep. uberis, and Strep. dysgalactiae isolated from bovine mastitis samples. The strains had been grown in brain-heart infusion broth (Scharlau, Barcelona, Spain) at $37^{\circ} \mathrm{C}$ for $24 \mathrm{~h}$, identified by biochemical tests and the API Staph System (BioMérieux, Rome, Italy), and then stored at $-70^{\circ} \mathrm{C}$ in a nutrient broth enriched with $15 \%$ glycerol. Genomic DNA was then isolated from both sterile saline solution and sterile bovine milk inoculated using the procedure described in Table 1, starting from step 2 when sterile saline solution was used.

To evaluate and optimize our extraction procedure, 30 bovine and caprine milk samples containing high 
Table 2. Bovine and caprine milk samples processed and their characteristics

\begin{tabular}{|c|c|c|c|c|c|c|}
\hline Sample ID & Source & Bacterial species & $\mathrm{SCC}, \times 10^{3}$ & Fat, \% & Protein, $\%$ & $\begin{array}{l}\text { Count, } \\
\text { cfu/mL }\end{array}$ \\
\hline 164 & Bovine & Staph. aureus & 2,398 & 3.27 & 2.98 & $4 \times 10^{3}$ \\
\hline 133 & Bovine & Staph. aureus & 400 & 3.00 & 3.39 & $2 \times 10^{3}$ \\
\hline 26 & Bovine & Staph. aureus & 547 & 3.43 & 3.24 & $2 \times 10^{2}$ \\
\hline 180 & Bovine & Staph. aureus & 451 & 4.19 & 3.55 & $5 \times 10^{2}$ \\
\hline 1445 & Bovine & Staph. aureus & 1,416 & 3.35 & 3.36 & $>10^{5}$ \\
\hline 55 & Bovine & Staph. aureus & 1,017 & 2.78 & 3.39 & $4 \times 10^{3}$ \\
\hline 94 & Bovine & Staph. aureus & 228 & 4.04 & 3.83 & $2 \times 10^{3}$ \\
\hline 247 & Bovine & Staph. aureus & 3,184 & 4.90 & 2.78 & $>10^{5}$ \\
\hline 76 & Bovine & Staph. aureus & 2,413 & 3.95 & 3.13 & $>10^{5}$ \\
\hline 9 & Caprine & Staph. aureus & 1,118 & 2.58 & 3.03 & $5 \times 10^{3}$ \\
\hline 4 & Caprine & Staph. aureus & 360 & 2.97 & 2.67 & $2 \times 10^{3}$ \\
\hline 12 & Caprine & Staph. aureus & 1,327 & 3.40 & 3.10 & $6 \times 10^{4}$ \\
\hline 18 & Caprine & Staph. aureus & 1,024 & 3.26 & 3.23 & $2 \times 10^{3}$ \\
\hline 3 & Caprine & Staph. aureus & 1,211 & 3.10 & 3.36 & $10^{3}$ \\
\hline 24 & Caprine & Staph. aureus & 490 & 2.74 & 3.46 & $5 \times 10^{3}$ \\
\hline 114 & Bovine & Strep. uberis & 2,071 & 4.51 & 2.89 & $>10^{5}$ \\
\hline 505 & Bovine & Strep. uberis & 1,850 & 5.49 & 3.44 & $>10^{5}$ \\
\hline 195 & Bovine & Staph. aureus & 205 & 6.06 & 4.05 & $>10^{5}$ \\
\hline 58 & Bovine & Staph. aureus & 2,235 & 4.70 & 3.34 & $>10^{5}$ \\
\hline 57 & Bovine & Staph. aureus & 2,332 & 3.74 & 3.68 & $>10^{5}$ \\
\hline 5 & Caprine & Staph. aureus & 410 & 2.27 & 2.97 & $10^{2}$ \\
\hline 15 & Caprine & Staph. aureus & 1,078 & 2.58 & 3.36 & $10^{4}$ \\
\hline 3 & Caprine & Staph. aureus & 1,296 & 3.00 & 3.34 & $5 \times 10^{3}$ \\
\hline 690 & Bovine & Strep. agalactiae & 860 & 4.24 & 3.44 & $>10^{5}$ \\
\hline 480 & Bovine & Strep dysgalactiae & 378 & 4.75 & 3.96 & $>10^{5}$ \\
\hline 520 & Bovine & Strep. dysgalactiae & 457 & 5.10 & 4.03 & $>10^{5}$ \\
\hline 791 & Bovine & Strep dysgalactiae & 952 & 3.90 & 3.40 & $>10^{5}$ \\
\hline 771 & Bovine & Strep. uberis & 1,316 & 2.97 & 2.89 & $>10^{5}$ \\
\hline 519 & Bovine & Strep. uberis & 974 & 3.89 & 3.22 & $>10^{5}$ \\
\hline 682 & Bovine & Strep. agalactiae & 784 & 3.74 & 3.53 & $>10^{5}$ \\
\hline
\end{tabular}

SCC were processed for bacterial DNA extraction and identification (Table 2).

For Staph. aureus, total sample counts were obtained by following the FIL-IDF standard procedure (no. 145A; 1997). Briefly, 10-fold serial dilutions were plated onto Baird Parker rabbit plasma fibrinogen agar plates, which were then incubated at $37^{\circ} \mathrm{C}$ for 24 and $48 \mathrm{~h}$, and observed for characteristic colony morphology. Streptococcal strains were grown at $37^{\circ} \mathrm{C}$ on blood agar plates (agar base supplemented with 5\% defibrinated sheep blood; Oxoid, Milan, Italy) for 24 to $48 \mathrm{~h}$.

Genomic DNA was isolated from milk samples following the procedure described in Table 1, starting from step 1. The extraction protocol required approximately 90 min to process the samples from sample receipt to DNA rehydration.

At the same time, DNA extractions were carried out starting with $200 \mu \mathrm{L}$ each of the 2 bovine milk samples described in Table 2 and using 2 commercial kits, the Puregene DNA Isolation kit for gram-positive bacteria (Gentra Systems, Minneapolis, MN) and the Wizard Genomic DNA Purification kit (Promega Italia, Milan, Italy) according to the manufacturer's instructions or with minor modifications (Ercolini et al., 2004). The quantity and quality of DNA samples were measured using a NanoDrop ND-1000 spectrophotometer (NanoDrop Technologies, Wilmington, DE).

\section{PCR Reactions}

All PCR reactions were carried out in a GeneAmp PCR System 2700 (Applied Biosystems, Foster City, $\mathrm{CA}$ ) in $0.2-\mathrm{mL}$ tubes containing $12.5 \mu \mathrm{L}$ of $2 \times \mathrm{PCR}$ Master Mix (Fermentas, M-Medical SRL, Milan, Italy), $0.1 \mu \mathrm{L}$ of each of the primers, $5 \mu \mathrm{L}$ of extracted DNA, and sterile water in a total reaction volume of $25 \mu \mathrm{L}$.

For Staph. aureus detection, a pre-PCR step was run at $94^{\circ} \mathrm{C}$ for $5 \mathrm{~min}$ followed by 30 PCR cycles under the following conditions: denaturation at $94^{\circ} \mathrm{C}$ for $1 \mathrm{~min}$, annealing at $56^{\circ} \mathrm{C}$ for $1 \mathrm{~min}$, and extension at $72^{\circ} \mathrm{C}$ for $1 \mathrm{~min}$. After the final cycle, the preparation was kept at $72^{\circ} \mathrm{C}$ for $10 \mathrm{~min}$ to complete the reaction. The Staph. aureus specific primers for the 23S rRNA gene are described in Cremonesi et al. (2005): 23S-F $5^{\prime}$ AGC TGT GGA TTG TCC TTT GG 3'; 23S-R 5' TCG CTC GCT CAC CTT AGA AT 3'.

Streptococci primers (i.e., primers for Strep. agalactiae, Strep. uberis, and Strep. dysgalactiae) and PCR annealing temperatures were derived from Riffon et al. (2001). According to this protocol, a pre-PCR step at 
$94^{\circ} \mathrm{C}$ for 2 min was run followed by 35 PCR cycles under the following conditions: denaturation at $94^{\circ} \mathrm{C}$ for $45 \mathrm{~s}$, annealing for $1 \mathrm{~min}$ at $60^{\circ} \mathrm{C}$ for Strep. agalactiae, at $59^{\circ} \mathrm{C}$ for Strep. uberis and at $57^{\circ} \mathrm{C}$ for Strep. dysgalactiae, respectively, and extension at $72^{\circ} \mathrm{C}$ for $2 \mathrm{~min}$. After the final cycle, the preparation was kept at $72^{\circ} \mathrm{C}$ for 10 min to complete the reaction.

The $\beta$-casein primers and PCR conditions were derived from Klotz and Einspainer (2001). Briefly, a prePCR step at $94^{\circ} \mathrm{C}$ for 4 min was run followed by 30 PCR cycles under the following conditions: denaturation at $94^{\circ} \mathrm{C}$ for $50 \mathrm{~s}$, annealing at $60^{\circ} \mathrm{C}$ for $50 \mathrm{~s}$, and extension at $72^{\circ} \mathrm{C}$ for $50 \mathrm{~s}$. After the final cycle, the preparation was kept at $72^{\circ} \mathrm{C}$ for $7 \mathrm{~min}$ to complete the reaction.

Ten microliters of each of the PCR-amplified products were analyzed by electrophoresis on $2 \%$ agarose gel stained with ethidium bromide $(0.05 \mu \mathrm{g} / \mu \mathrm{L}$; Sigma Aldrich, Milan, Italy). After an electrophoresis run-time of $30 \mathrm{~min}$, the gels were photographed under UV light using the BioProfile system (Mitsubishi, Tokyo, Japan). Molecular size markers (100-bp and 1-kb DNA ladder; Finnzymes, Espoo, Finland) were included in each agarose gel.

\section{Sensitivity Tests}

The sensitivity of our extraction method was examined using sterilized bovine milk inoculated with dilutions of mixed cultures of Staph. aureus (ATCC 23235) and Strep. agalactiae strains, starting from $10^{7} \mathrm{cfu} / \mathrm{mL}$. Parallel dilutions of Staph. aureus and Strep. agalactiae strains were made in sterile saline solution. Dilutions obtained were then plated on sheep blood agar. Numbers of bacterial colonies were counted after $24 \mathrm{~h}$ of incubation, and ranged from $<10^{2}$ to $10^{7} \mathrm{cfu} / \mathrm{mL}$ for both Staph. aureus and Strep. agalactiae strains. Unbalanced mixed cultures were tested at the following concentrations: $10^{2} \mathrm{cfu} / \mathrm{mL}$ of Staph. aureus with $10^{2} \mathrm{cfu} /$ $\mathrm{mL}$ of Strep. agalactiae, $10^{4} \mathrm{cfu} / \mathrm{mL}$ of Staph. aureus with $10^{2} \mathrm{cfu} / \mathrm{mL}$ of Strep. agalactiae, $10^{4} \mathrm{cfu} / \mathrm{mL}$ of Staph. aureus with $10^{3} \mathrm{cfu} / \mathrm{mL}$ of Strep. agalactiae and $10^{7} \mathrm{cfu} / \mathrm{mL}$ of Staph. aureus with $10^{2} \mathrm{cfu} / \mathrm{mL}$ of Strep. agalactiae, respectively. The PCR reactions for Staph. aureus and Strep. agalactiae strains were carried out separately following the PCR conditions described above.

\section{RESULTS AND DISCUSSION}

As described in previous studies (Gutierrez et al., 1997; Romero and Lopez-Goni, 1999; Ramesh et al., 2002), a PCR-based assay can be extremely useful for analyzing pure microbial cultures. However, when applied directly to food samples, its efficiency can be mark- edly reduced by poor sample preparation, which might inadvertently introduce inhibitory substances precluding DNA amplification. Fats, proteinases, and high concentrations of $\mathrm{Ca}^{2+}$ (Wilson, 1997) have been proposed as potential inhibitors of PCR. In our protocol, modifications made to the original procedures (Malferrari et al., 2002) consisted of pretreatment of samples to eliminate PCR inhibitors such as milk fats and proteins. Furthermore, the robustness of bacterial cells with special reference to gram-positive bacteria (in our case Staphylococcus and Streptococcus species) necessitated the use of enzymes such as lysozyme, lysostaphin, and lyticase to guarantee total DNA release from lysed cells (Riffon et al., 2001; Meiri-Bendek et al., 2002). In our study, efficient lysis of cells and removal of inhibitors were accomplished by increasing the concentration of guanidine thiocyanate and lysis buffer solution, both of which increased the disruption of bacterial cells, resulting in stronger and more reproducible amplification, avoiding the combination of enzymes and incubation conditions, and maintaining good characteristics of the method without time-consuming procedures.

The specific PCR amplifications obtained from sterile bovine milk inoculated with Staph. aureus, Strep. agalactiae, Strep. dysgalactiae, and Strep. uberis ranging from $<10$ to $10^{7} \mathrm{cfu} / \mathrm{mL}$ are shown in Figure 1. A quantitative decrease in the intensity of the amplicons reflected a corresponding decrease in cell numbers. Amplification of these species-specific DNA sequences is a necessary positive control to confirm the efficiency of DNA extraction as well as the quality of the DNA being amplified. This is an important step for studies in which detection of pathogenic DNA is carried out using PCR amplification. Furthermore, all samples obtained from sterile bovine milk inoculated with Staph. aureus, Strep. agalactiae, Strep. dysgalactiae, and Strep. uberis were successfully amplified, also confirming the absence of potential inhibitory factors.

Sensitivity of the extraction procedure was found to achieve a detection of $10 \mathrm{cfu} / \mathrm{mL}$ for all species, both in milk and sterilized saline solution. The detection level of our method eliminates the need for bacterial enrichment culturing of Staphylococcus and Streptococcus species.

Presence of coexisting bacteria in a milk sample can attenuate the specific detection of the target bacterial species (Ramesh et al., 2002). The sensitivity of the DNA extraction procedure for identifying a specific bacterial pathogen in the presence of a coexisting microbe is shown in Figure 2. Staphylococcus aureus and Strep. agalactiae in concentrations ranging from $<10^{2}$ to $10^{7}$ $\mathrm{cfu} / \mathrm{mL}$ could be detected simultaneously, even when they coexisted in milk at concentrations as low as $10^{2}$ $\mathrm{cfu} / \mathrm{mL}$. 


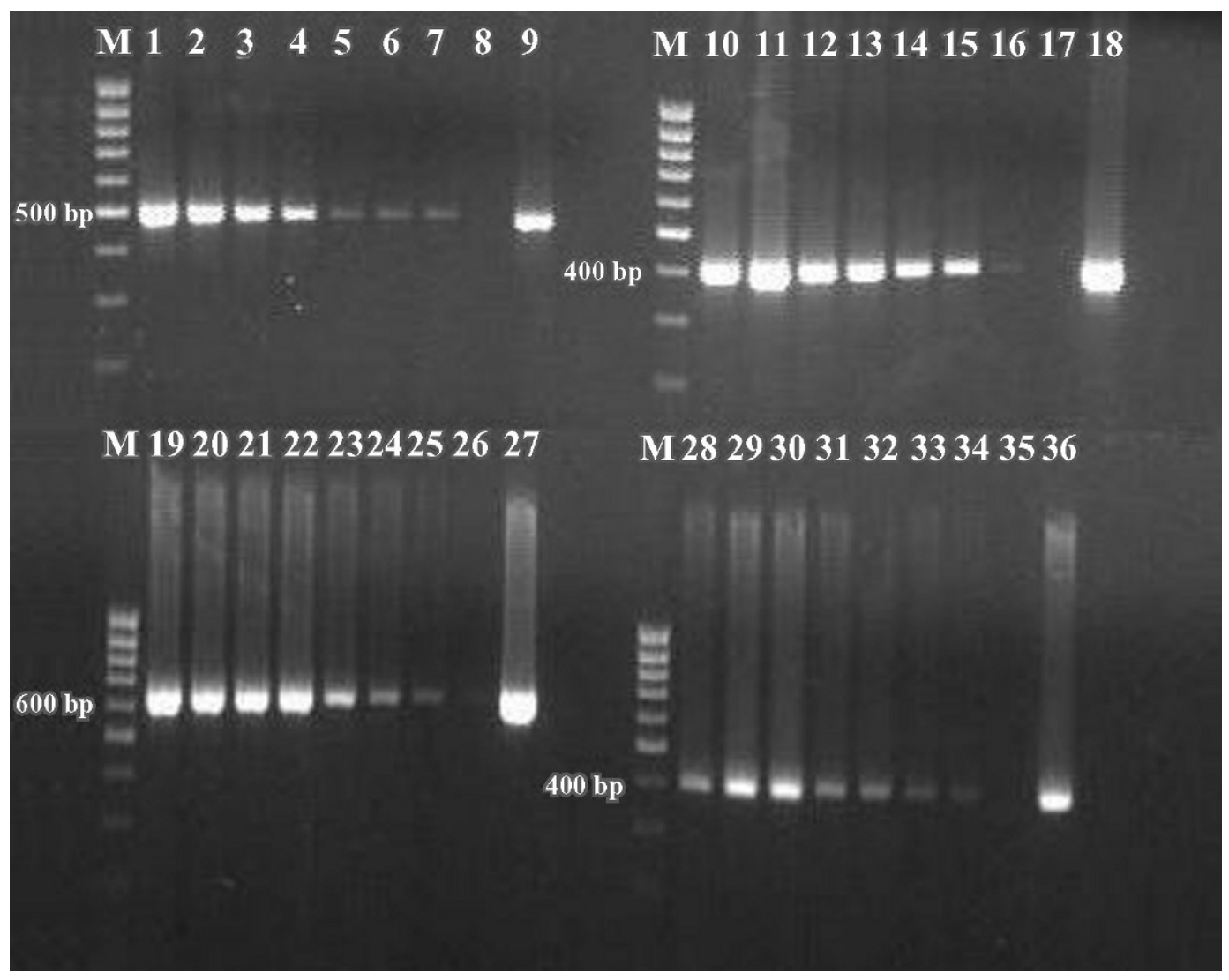

Figure 1. Sensitivity of PCR assay in detecting DNA from milk samples artificially inoculated with Staphylococcus aureus (ATCC 23235, reference strain), Streptococcus agalactiae, Streptococcus dysgalactiae, and Streptococcus uberis target genes. The amounts of the bacteria used were from $2 \times 10^{7}$ to $2 \times 10 \mathrm{cfu} / \mathrm{mL}$ for Staph. aureus (lanes 1 to $7,499 \mathrm{bp}$ ), from $5 \times 10^{7}$ to $5 \times 10 \mathrm{cfu} / \mathrm{mL}$ for Strep. agalactiae (lanes 10 to $16,405 \mathrm{bp}$ ), from $7 \times 10^{7}$ to $7 \times 10 \mathrm{cfu} / \mathrm{mL}$ for Strep. uberis (lanes 19 to $25,624 \mathrm{bp}$ ), and from $2 \times 10^{7}$ to $2 \times 10 \mathrm{cfu} / \mathrm{mL}$ for Strep. dysgalactiae (lanes 28 to 34, $401 \mathrm{bp}$ ). Positive controls for Staph. aureus (lane 9), Strep. agalactiae (lane 18), Strep. uberis (lane 27), and Strep. dysgalactiae (lane 36) and negative controls (uninoculated milk, lanes 8, 17, 26, and 35) were included; M = 100-bp DNA ladder (Finnzymes, Espoo, Finland).

To validate our extraction assay, 30 bovine and caprine milk samples with high SCC were processed for bacterial DNA extraction and identification (Table 2). All samples extracted were successfully amplified using target bacteria-specific primers. Identification of pathogens obtained by PCR assays was in full agreement with that obtained by microbiological methods (data not shown).

Furthermore, to evaluate the relative effectiveness of our method in recovering bacterial DNA from milk samples, we compared our procedure to 3 existing protocols. Two of the existing protocols are reported in the literature for direct DNA extraction of gram-positive bacteria from raw milk and are based on the use of a commercial kit used according to the manufacturer's instructions (Furet et al., 2004) or with minor modifications (Ercolini et al., 2004). The third DNA extraction was performed using a commercial kit to extract DNA from gram-positive bacteria in culture. Two bovine milk samples containing $>10^{5} \mathrm{cfu} / \mathrm{mL}$ of Staph. aureus were tested to compare these methods for DNA recovery and their compatibility with PCR detection.

The quality and the quantity of DNA extracted are shown in Table 3. In addition, all DNA samples were analyzed by PCR using primers to amplify the $\beta$-casein gene and Staph. aureus 23S rRNA gene (Figure 3). As shown in Table 3, our method yielded higher concentrations of DNA than did the other methods. Reasons for decreased DNA recoveries reported for other methods are unknown, but might include lost DNA template through degradation or difficulty in disrupting bacterial cell walls. Furthermore, PCR analysis of samples extracted using the diverse procedures provided good detection levels of the $\beta$-casein gene with the exception of the Puregene DNA Isolation kit; different detection levels of the target bacterial gene are probably due to differences in bacterial DNA extraction efficiency. 


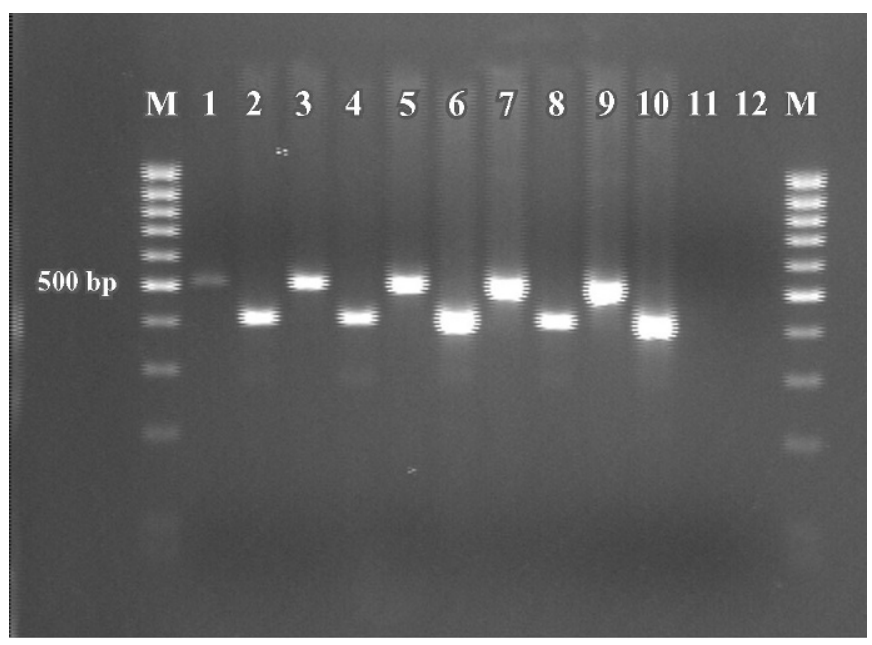

Figure 2. Sensitivity test using PCR for simultaneous detection using unbalanced mixes of Staphylococcus aureus 23235 ATCC reference strain and Streptococcus agalactiae in milk samples. Lanes 1 and $2=\operatorname{mix}$ with Staph. aureus $10^{2} \mathrm{cfu} / \mathrm{mL}$ and Strep. agalactiae $10^{2}$ $\mathrm{cfu} / \mathrm{mL}$, respectively; lanes 3 and $4=\mathrm{mix}$ with Staph. aureus $10^{4} \mathrm{cfu} /$ $\mathrm{mL}$ and Strep. agalactiae $10^{2} \mathrm{cfu} / \mathrm{mL}$, respectively; lanes 5 and $6=$ mix with Staph. aureus $10^{4} \mathrm{cfu} / \mathrm{mL}$ and Strep. agalactiae $10^{3} \mathrm{cfu} / \mathrm{mL}$, respectively; lanes 7 and $8=\operatorname{mix}$ with Staph. aureus $10^{7} \mathrm{cfu} / \mathrm{mL}$ and Strep. agalactiae $10^{2} \mathrm{cfu} / \mathrm{mL}$, respectively; lane 9 = positive control for Staph. aureus; lane $10=$ positive control for Strep. agalactiae; lanes 11 and $12=$ milk without bacterial contamination; $\mathrm{M}=100$ bp DNA ladder (Finnzymes, Espoo, Finland).

Although sensitivity of a DNA extraction method is important, many additional factors must be considered, including time required, cost per test, and the need for specific reagents. In addition, a protocol that does not include specialized equipment or knowledge supports the routine isolation of DNA from a large series of samples (Boom et al., 1990). Processing time varied among procedures. Sample processing by our method required approximately $90 \mathrm{~min}$; processing time by the other methods varied from 130 to 140 min (Ercolini et al.,

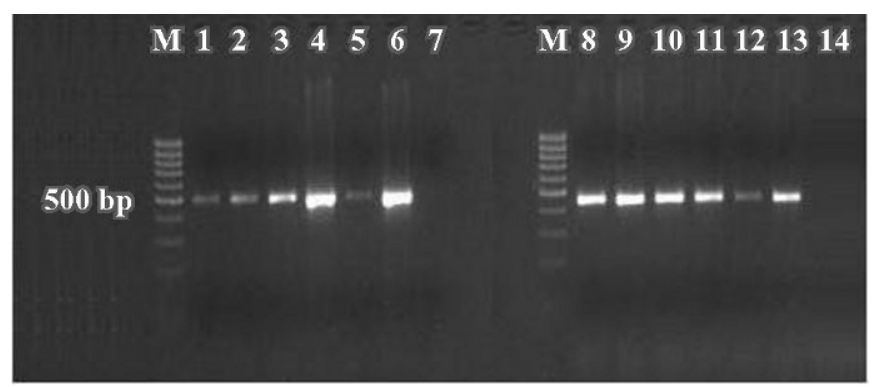

Figure 3. Effect of DNA extraction using 4 different procedures on the PCR detection of Staph. aureus and bovine genomic DNA using primers for Staph. aureus 23S rRNA gene (lanes 1 to 7, 499 bp) and bovine $\beta$-casein gene (lanes 8 to 14, $453 \mathrm{bp}$ ). Lanes 1 and $8=$ DNA extracted according to Ercolini et al. (2004); lanes 2 and $9=$ DNA extracted by Wizard Genomic DNA Isolation kit (Promega); lanes 3 and $10=$ DNA extracted following our procedure; lanes 4 and 11 = DNA extracted following our procedure, with a second elution step; lanes 5 and $12=$ DNA extracted by Puregene DNA isolation kit (Gentra Systems). Lanes 6 and $13=$ positive controls; lanes 7 and $14=$ negative controls (no DNA); M = 100-bp DNA ladder (Finnzymes, Espoo, Finland).

2004), and up to $3 \mathrm{~h}$ for the Puregene DNA Isolation kit. In total, the method described herein requires a total time of less than $6 \mathrm{~h}$ (for DNA extraction, PCR amplification, and gel band visualization).

In addition to decreased processing time, our procedure reduced the number of manipulations needed to obtain pure DNA, improving the ease of sample handling, and minimizing the risk of cross-contamination. The present procedure for DNA preparation is rapid, simple, and reproducible, providing a more efficient protocol applicable directly to milk samples, which remains unaffected by matrix-derived factors, potential inhibitors, and the presence of coexisting bacteria. Therefore, the DNA extraction method developed in the present study generates PCR-compatible templates without need for enrichment of the samples.

Table 3. Efficiency of 4 different DNA extraction methods tested on 2 samples

\begin{tabular}{llll}
\hline & & $\begin{array}{l}\text { DNA } \\
\text { concentration, } \\
\text { ng/ } / \mathrm{L}\end{array}$ & $\begin{array}{l}\text { DNA } \\
\text { purity, } \\
\mathrm{A}_{260} / \mathrm{A}_{280}\end{array}$ \\
\hline 57 & DNA extraction procedure & 10.2 & 1.76 \\
57 & Ercolini et al., 2004 & 8.3 & 2.16 \\
57 & Wizard Genomic DNA Purification kit ${ }^{1}$ & 22.9 & 1.73 \\
$57 \mathrm{II}$ & Our procedure & 22.2 & 1.88 \\
57 & Our procedure with second elution step ${ }^{2}$ & 12.0 & 1.76 \\
58 & Puregene DNA Isolation kit & & 1.69 \\
58 & Ercolini et al., 2004 & 18.4 & 2.03 \\
58 & Wizard Genomic DNA Purification kit & 10.5 & 1.79 \\
$58 \mathrm{II}$ & Our procedure & 23.1 & 1.92 \\
58 & Our procedure with second elution step & 14.7 & 1.93 \\
\hline
\end{tabular}

${ }^{1}$ Promega Italia, Milan, Italy.

${ }^{2} \mathrm{~A}$ second elution step performed by our DNA extraction procedure (as described in Table 1).

${ }^{3}$ Gentra Systems, Minneapolis, MN. 
The procedure described herein could be automated using a liquid handling system to allow for highthroughput screening. Indeed, good preliminary results were obtained when the procedure was implemented on the Multiprobe II HT EX (Perkin Elmer) liquid handling system (data not shown). As described in Malferrari et al. (2004), the technology provided significant improvements in terms of efficiency, quality, and cost reduction.

\section{ACKNOWLEDGMENTS}

Part of this work was funded by the Fondazione Cariplo (contract no. 2003.1824/10.8441) and by Italian FIRST 2004 (to Paolo Moroni).

\section{REFERENCES}

Boom, R., C. J. A. Sol, M. M. M. Salimans, C. L. Jansen, P. M. E. Wertheim-van Dillen, and J. Noordaa. 1990. Rapid and simple method for purification of nucleic acids. J. Clin. Microbiol. 28:495-503.

Cremonesi, P., M. Luzzana, M. Brasca, S. Morandi, R. Lodi, C. Vimercati, D. Agnellini, G. Caramenti, P. Moroni, and B. Castiglioni. 2005. Development of a multiplex PCR assay for the identification of Staphylococcus aureus enterotoxigenic strains isolated from milk and dairy products. Mol. Cell. Probes 19:299-305.

Ercolini, D., G. Blaiotta, V. Fusco, and S. Coppola. 2004. PCR-based detection of enterotoxigenic Staphylococcus aureus in the early stages of raw milk cheese making. J. Appl. Microbiol. 96:10901096.

Forsman, P., A. Tilsala-Timisjarvi, and T. Alatossava. 1997. Identification of staphylococcal and streptococcal causes of bovine mastitis using 16S-23S rRNA spacer regions. Microbiology 143:3491-3500.

Furet, J. P., P. Quénée, and P. Tailliez. 2004. Molecular quantification of lactic acid bacteria in fermented milk products using real-time quantitative PCR. Int. J. Food Microbiol. 97:197-207.

Gutierrez, R., T. Garcia, I. Gonzalez, B. Sanz, P. E. Hernandez, and R. Martin. 1997. A quantitative PCR-ELISA for the rapid enumer- ation of bacteria in refrigerated raw milk. J. Appl. Microbiol. 83:518-523.

Klotz, A., and R. Espainer. 2001. Development of a DNA-based screening method to detect cow milk in ewe, goat and buffalo milk and dairy products using PCR-LCR-EIA technique. Milchwissenschaft 56:67-70.

Malferrari, G., E. Monferini, P. DeBlasio, G. Diaferia, G. Saltini, E. Del Vecchio, L. Rossi-Bernardi, and I. Biunno. 2002. High-quality genomic DNA from human whole blood and mononuclear cells. Biotechniques 33:1228-1230.

Malferrari, G., E. Monferini, S. Michelini, M. C. Proverbio, L. Biagiotti, G. Saltini, F. Gervasi, P. DeBlasio, and I. Biunno. 2004 Automated system for nucleic acid extraction, purification and analysis. Nucleic Acids Purif. 6:52-54.

Meiri-Bendek, I., E. Lipkin, A. Friedmann, G. Leitner, A. Saran, S. Friedman, and Y. Kashi. 2002. A PCR-based method for the detection of Streptococcus agalactiae in milk. J. Dairy Sci. 85:1717-1723.

National Mastitis Council. Current Concepts of Bovine Mastitis.1998. 4th ed. Natl. Mastitis Council, Madison, WI.

Phuektes, P., G. F. Browning, G. Anderson, and P. Mansell. 2003 Multiplex polymerase chain reaction as a mastitis screening test for Staphylococcus aureus, Streptococcus agalactiae, Streptococcus dysgalactiae and Streptococcus uberis in bulk milk samples. J. Dairy Res. 70:149-155.

Phuektes, P., P. Mansell, and G. F. Browning. 2001. Multiplex polymerase chain reaction assay for simultaneous detection of Staphylococcus aureus and streptococcal causes of bovine mastitis. J. Dairy Sci. 84:1140-1148.

Ramesh, A., B. P. Padmapriya, A. Chandrashekar, and M. C. Varadaraj. 2002. Application of a convenient DNA extraction method and multiplex PCR for the direct detection of Staphylococcus aureus and Yersinia enterocolitica in milk samples. Mol. Cell. Probes 16:307-314.

Riffon, R., K. Sayasith, H. Khalil, P. Dubreuil, M. Drolet, and J. Lagacè. 2001. Development of a rapid and sensitive test for identification of major pathogens in bovine mastitis by PCR. J. Clin. Microbiol. 39:2584-2589.

Romero, C., and I. Lopez-Goni. 1999. Improved method for purification of bacterial DNA from bovine milk for detection of Brucella spp. by PCR. Appl. Environ. Microbiol. 65:3735-3737.

Rossen, L., P. Norskov, K. Holmstrom, and O. F. Rasmussen. 1992. Inhibition of PCR by components of food samples, microbial diagnostic assays and DNA-extraction solutions. Int. J. Food Microbiol. 17:37-45.

Wilson, I. G. 1997. Inhibition and facilitation of nucleic acid amplification. Appl. Environ. Microbiol. 63:3741-3751. 